IJAMSR 3 (4) www.ijamsr.com CrossRef: https://doi.org/10.31426/ijamsr.2020.3.4.3211

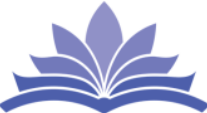

International Journal of

I J A M S R

Advanced Multidisciplinary Scientific Research (IJAMSR) ISSN:2581-4281

\title{
Contribution of Project-Based Blended Learning (PjB2L) Learning Model to Technoprenuership Ability in Higher Education
}

\author{
Hariyono $^{1}$, Vera Septi Andrini ${ }^{2}$ \\ 1,2 STKIP PGRI Nganjuk, Jl.A.R. Saleh, Jawa Timur, Indonesia \\ Email: hariyono@stkipnganjuk.ac.id,
}

Keywords:

Blended Learning

Project Based Learning

Technopreneur

\begin{abstract}
A B S T R A C T
Technology plays an important role in various elements of life. The purpose of this research is to find out the application of technology in the form of learning models and its effectiveness in developing the ability of technologybased entrepreneurs or known as technopreneurship. The research sample is 151 students. The study uses quantitative descriptive correlational type method. Data collection techniques use documentation, interviews, and questionnaires. Data analysis uses correlation test. The learning process scenario uses the PjB2L model consisting of 11 steps, namely Define the problem and identify the information needed, Identify Information Seeking Strategies, Locate and Access Information, Extract Relevant Information, Synthesize Information, Evaluate the results of research, Communicate the information, Take appropriate action, Finalize the project, Present your final program / activity to the appropriate groups, and Assess your course of action, presentation, and the need for possible further action on your topic. Technopreneurship Competency is measured based on 4 aspects namely Interpersonal Skill, Intrapersonal Skill, Entrepreneurship Knowledge, and Approxite Technology Knowledge. The results show that the PjB2L learning model is effective in improving students' technopreneurship abilities. Correlation test shows the value of Sig. (2.tailed) between the PjB2L models to the ability of technopreneurship of 0,000. This means that there is a correlation between the PjB2L model and the ability of technopreneurship. Technopreneurship competency measurement results show interpersonal aspects with a score of 3.52 (very high category), intrapersonal aspects with a score of 3.60 (very high category), aspects entrepreneurship knowledge with score 3.20 (very high category), and aspects approxite technology knowledge with score 3.20 (very high category). Each aspect is measured based on indicators that have been determined.
\end{abstract}

Citation: Hariyono, Vera Septi Andrini (2020). Contribution of ProjectBased Blended Learning (PjB2L) Learning Model to Technoprenuership Ability in Higher Education: International Journal of Advanced Multidisciplinary Scientific Research (IJAMSR) ISSN:2581-4281, 3 (4), April, 2020, Pp 1 - 15 
IJAMSR 3 (4) www.ijamsr.com CrossRef: https://doi.org/10.31426/ijamsr.2020.3.4.3211

I J A M S R

\section{International Journal of Advanced Multidisciplinary Scientific Research (IJAMSR) ISSN:2581-4281}

\section{Introduction}

Based on data from the Central Statistics Agency (CSA) in 2019, the number of unemployed people in Indonesia rises by 50 thousand people (data as of August 2019). This result increased from 2018 by 7 million to 7.05 million people. More clearly can be seen in Figure 1. If seen from Figure 1, between 2015 and 2016 there was a very good trend because the unemployment rate in Indonesia experienced a significant decline. The decline also occurred between 2017 and 2018 . However, between 2018 and 2019 there was a significant increase. Even with the COVID-19 pandemic, it is estimated that unemployment in 2020 will continue to grow by around 5 million people. Meanwhile, the highest number of unemployed from vocational graduates was $8.49 \%$, high school was $6.77 \%$, Diploma was $6.76 \%$, university graduates were $5.73 \%$, junior high was $5.02 \%$, and elementary school $2.64 \%$. When viewed from the age sector, unemployment was mostly dominated by young people, which is the age of 15-24 years, which was recorded at $16.28 \%$ and aged $25-59$ years was only $3.23 \%$. (CSA 2020 data).

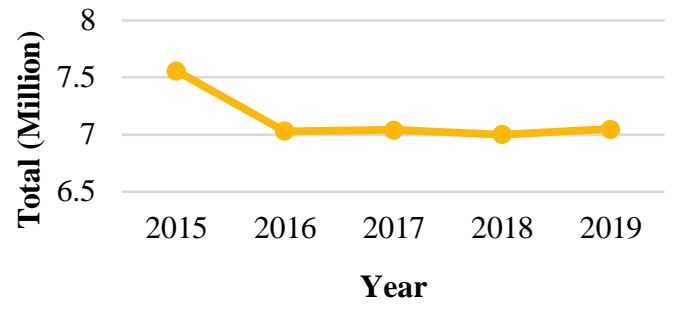

Figure 1. Data on Total Unemployment in Indonesia from 2015 to 2019

Referring to the conditions above, a solution is needed to reduce the increasing number of unemployed people in Indonesia. One of them is through efforts to accelerate the growth of new businesses. If assessed by age, it can be seen that the productive age of 15-24 years dominates the unemployment rate. This is caused by the mindset of graduates who are still aiming at job seekers rather than job creators. Therefore, the role of all levels of education, especially tertiary institutions, is highly needed in improving human resources to be better prepared to face the existing competition. Hidayat, H., Tamin, BY, Herawati, S., Khairul, K., \& Syahmaidi, E. (2019).

STKIP PGRI Nganjuk has made various efforts such as providing provision of entrepreneurial skills such as the application of entrepreneurship courses, industrial internships, providing business centres to help student entrepreneurs, holding entrepreneurial 
IJAMSR 3 (4) www.ijamsr.com CrossRef: https://doi.org/10.31426/ijamsr.2020.3.4.3211

\section{J A M S R}

\section{International Journal of Advanced Multidisciplinary Scientific Research (IJAMSR) ISSN:2581-4281}

competitions, and implementing innovative technology-based learning models to follow the digitalization era competition (Suharto \& TW Maduretno , 2010). Data for 2019, there are 104 students who have businesses with various products that have been created ranging from the food sector, beverages, services, fashion, agriculture, animal husbandry, and others. Therefore, from 104 entrepreneurs are still not running optimally. The survey results show that there are still many obstacles faced such as low entrepreneurial mental attitude by $66 \%$ and the use of technology in supporting entrepreneurs by $34 \%$.

Referring to the existing problems, the focus of this research is the application of innovative learning models by integrating the Project Based Learning (PBL) model with Blended Learning $(\mathrm{BL})$ or abbreviated as $\mathrm{PjB} 2 \mathrm{~L}$ in an effort to improve students' technopreneurship abilities. PjB2L or known as Project Based Blended Learning is a learning concept that combines face-to-face learning with online learning (synchronous and asynchronous). Through the PjB2L learning concept, students are trained to express facts, ideas, and conclusions through given project assignments. In addition, also trained the ability to find and explore information from various internetbased sources Wahyudi, W., \& Winanto, A. (2018). In its application, Furthermore, integration of both can increase student motivation and communication skills. Other research results also mentioned, the integration of blended and PBL is more effective than traditional PBL learning models. Ammann, D., Vignoli, Y., \& Kaap-Fröhlich, S. (2019). Car, LT, Kyaw, BM, Dunleavy, G., Smart, NA, Semwal, M., Rotgans, JI, ... \& Campbell, J. (2019). Shimizu, I., Nakazawa, H., Sato, Y., Wolfhagen, IH, \& Könings, KD (2019). Another impact of the combination of face to face learning with effective online-based learning is being able to increase student activity. Lecturers and students can communicate and interact directly whenever and wherever. Students can search for project materials from various sources without any limitations Ma, H. (2016).

In the research conducted, the dependent variable studied was the ability of students' technopreneurship at STKIP PGRI Nganjuk. Globalization of the economy and the development of the era of digitalization from various sectors, especially industry require students to have high ability in 
IJAMSR 3 (4) www.ijamsr.com CrossRef: https://doi.org/10.31426/ijamsr.2020.3.4.3211

entrepreneurship. The presence of technology should be followed in efforts to improve the quality and management of businesses. Technology-based entrepreneurship or known as technopreneurship is a way to process various products so that cost and time efficiency results in producing quality products (Walker, K. (2012). (Okorie, NN, Kwa, DY, Olusunle, SOO, Akinyanmi, AO, \& Momoh, IM (2014) Technopreneurship is a combination of science technology and entrepreneurship with the aim of creating quality products, good management and standards, so that they can bring profits through business processes. The ability of technopreneurship needs to be taught from an early age so that students are better prepared to face the world of work.

Therefore, in this study an innovation was made on the learning model in order to be able to increase the activeness, motivation, and ability of students in technopreneurship. The media used in this research is a website-based application to provide Moodle type online learning services.

\section{Method}

This research uses quantitative descriptive correlational type method. Data analysis uses correlation test which aims to determine the contribution of independent variables to the dependent variable. The independent variable (X) is the Project-Based Blended Learning $(\mathrm{PjB} 2 \mathrm{~L})$ model and the dependent variable $(\mathrm{Y})$ is the ability of technoprenuership. Data analysis uses SPSS program.

The study was conducted at STKIP PGRI Nganjuk. The study population was students of STKIP PGRI Nganjuk with a sample of 151 students. The data collection technique used purposing sampling which was done by taking SMT 7 students who took the Entrepreneurship Subject program. The implementation of the PjB2L learning model on the ability of technopreneurship can be seen in Figure 1. 
IJAMSR 3 (4) www.ijamsr.com CrossRef: https://doi.org/10.31426/ijamsr.2020.3.4.3211

\section{International Journal of Advanced Multidisciplinary Scientific Research (IJAMSR) ISSN:2581-4281}

PjB2L learning model

scenario:

1. Define the problem and identify the information needed

2. Identify Information Seeking Strategies

3. Locate and access information

4. Extract Relevant information

5. Synthesize information

6. Evaluate the results of research

7. Communicate the information

8. Take appropriate action

9. Finalize the project

10. Present your final program / activity to the appropriate groups

11. Assess your course of action, presentation, and the need for possible further actions on your topic

Figure 2. Application of the PBL2L Learning Model to Technopreneurship Capabilities

Data collection uses documentation, interviews, and questionnaires. Documentation is carried out to obtain information about learning outcomes and to know the ability of students in technopreneurship. While the questionnaire uses a Likert scale type which is also used to determine the ability of student technopreneurship. The hypothesis of this study is there is a relationship or correlation between Project-Based Blended Learning (PjB2L) model of students' technoprenuership abilities.

\section{Result}

Based on the research that has been done, the learning scenario obtained by the PjB2L model can be explained as follows:

\section{Step 1: Define the problem and identify the information needed}

At this stage, face-to-face activities in class begin with identifying problems, finding the information needed, and continuing with the selection of topics, and determining the project. The main topic in this research is the concept of technopreneurship. Next, the project determination step is carried out by conducting field observations and analysis of potential entrepreneurs in Nganjuk Regency, East Java, Indonesia through various sources such as social media, the Nganjuk Indonesian Young Student Association, and market surveys. During the identification process, students can consult with the lecturer through the ELearning (Moodle) platform that has been prepared.

The analysis shows that there is a lot of local potentials that can still be developed to become an entrepreneurial topic such as various foods, beverages, agriculture and animal husbandry, services, clothing, and others. The ultimate 
IJAMSR 3 (4) www.ijamsr.com CrossRef: https://doi.org/10.31426/ijamsr.2020.3.4.3211

\section{J A M S R}

\section{International Journal of Advanced Multidisciplinary Scientific Research (IJAMSR) ISSN:2581-4281}

goal of learning, students are trained to learn to find information offline and online. This activity helps students develop analytical skills, how to use technology positively, and foster motivation. The concept of learning becomes more interesting because the lecturer is able to combine face-to-face learning with online. Yulastri, A., \& Hidayat, H. (2017).

\section{Step 2: Identify Information Seeking}

\section{Strategies (Make a hypothesis, choose a}

topic, and develop several research sources)

At this stage, information processing is carried out, making hypotheses, determining topics, and developing resources. Information processing covers aspects of production and marketing. The topic created refers to a technology-based entrepreneurship (technopreneurship) project.

The results of the identification of topics in the food entrepreneurship sector such as Onion Chips (KRIBAW), Pare Chips, Banana Stem Chips, various nugget, cakes, bread, and others. The topics of the beverage entrepreneurial sector such as various traditional herbal drinks are various teas, various juices, coffee, and others. Topics from the fashion sector are such as various clothes, bags, shoes, headscarves, and others. Other topics are no less interesting such as organic vegetables and fruit, wall hangings,

\section{Step 3: Locate and access information}

At this stage, direct access to information on entrepreneurs is carried out in accordance with the specified topics. Investigation of entrepreneurs is carried out using interview techniques regarding the types of businesses owned, business management, and technology used. At this stage, students can explore information and learn directly from businesses to add references in determining business ideas. By knowing the actual business conditions of these business actors, students are more motivated to develop their business. Hidayat, H., Kusumaningrum, I., \& Mardin, A. (2017).

\section{Step 4: Extract relevant information}

At this stage, students make a summary of the results of the analysis starting from step 1 to step 3. Then make a business plan based on findings, opportunities, create new ideas, and look for technology-based entrepreneurial innovations. 
IJAMSR 3 (4) www.ijamsr.com CrossRef: https://doi.org/10.31426/ijamsr.2020.3.4.3211

\section{J A M S R}

\section{International Journal of Advanced Multidisciplinary Scientific Research (IJAMSR) ISSN:2581-4281}

\section{Step 5: Synthesize information}

At this stage, the design of technology-based entrepreneurship projects is communicated with lecturers to get input.

\section{Step 6: Evaluate the results of research}

At this stage, an evaluation of all business plan preparation starts from the preparation of products, tools and materials, infrastructure, location determination, and marketing.

\section{Step 7: Communicate the information}

At this stage, the final business plan is presented in class to get input.

\section{Step 8: Take appropriate action}

Carry out projects that have been planned according to a schedule that has been determined. Implementation

of entrepreneurship is done by integrating technology, not necessarily using high technology, but tends to have quality in accordance with product needs.

\section{Step 9: Finalize the project}

Finalization of the project is reported to the lecturer for suggestions and input. It is the weaknesses and strengths of the work done.
Step 10: Present your final program/activity to the appropriate groups

It is presentation and evaluation of entrepreneurial results. Evaluation is very important to look for compatibility between plans and work objectives.

\section{Step 11: Assess your course of action,} presentation, and the need for possible further actions on your topic

Assessment process and follow-up plans. At the end of the lesson, business projects that have been done are not merely to fulfill the course assignments. However, there is a follow-up to the sustain ability of the business that has been carried out. The evaluation of student entrepreneurship is carried out by the STKIP PGRI Nganjuk business center on a regular basis. The aim is to educate, evaluate, analyze weaknesses, and improve business quality.

In the learning process, face-to-face activities are carried out in full in the classroom so students can discuss and share information. This face-to-face interaction can help communication skills between students and lecturers effectively, facilitate the feedback process, and be able to motivate learning 
IJAMSR 3 (4) www.ijamsr.com CrossRef: https://doi.org/10.31426/ijamsr.2020.3.4.3211

\section{International Journal of Advanced Multidisciplinary Scientific Research (IJAMSR) ISSN:2581-4281}

(Lalima, DK, \& Dangwal, KL (2017). Whereas online learning is done by using E-learning (Moodle) with the address http://ekwu.stkipnganjuk.ac.id/. Moodle feature contains (1) login \& logout which is a link in and out of the media, (2) course that contains lecture material, (3) Quiz contains practice questions, (4) Chat contains a means of discussion between lecturers and students which can be done by online, (4) Exam contains exam questions, (5) download contains download links on teaching materials, videos, animations, worksheets, and questionnaires.

In practice, the lecturer gives the material that has been provided at Moodle and students learn the material. To find out the ability of students, it is given assignments in the form of projects and quizzes at the end of learning. Project tasks and quizzes are uploaded on the menu that Moodle has provided. Lecturers can directly conduct assessments and even carry out discussions with students for improvement. The features provided by Moodle make it easier for lecturers and students to learn the material provided. Khasanah, M. (2019). All extensions in the form of doc, pdf, video, images, and others can be uploaded in the Moodle menu.

In the research conducted, the use of the $\mathrm{PjB} 2 \mathrm{~L}$ learning model is intended to improve students' technopreneurship abilities. Technopreneurship Competency is measured based on 4 aspects namely Interpersonal Skill, Intrapersonal Skill, Entrepreneurship Knowledge, and Approxite Technology Knowledge (Ismail, E., Samsudi, S., \& Widjanarko, D. (2017). The results of the analysis of technopreneurship competencies after the learning process can be displayed as Table 1.

Table 1. Results of the assessment pre-test and post-test on the learning model components Technopreneurship

\begin{tabular}{|l|c|c|c|c|}
\hline \multirow{2}{*}{ Rated Aspect } & \multicolumn{2}{c|}{ Pre-Test } & \multicolumn{2}{c|}{ Post-Test } \\
\cline { 2 - 5 } & $\begin{array}{c}\text { Aver } \\
\text { age }\end{array}$ & $\begin{array}{c}\text { Crite } \\
\text { ria }\end{array}$ & $\begin{array}{c}\text { Aver } \\
\text { age }\end{array}$ & $\begin{array}{c}\text { Criter } \\
\text { ia }\end{array}$ \\
\hline Interpersonal Skill & 2.47 & High & 3.52 & $\begin{array}{c}\text { Very } \\
\text { High }\end{array}$ \\
\hline Intrapersonal Skill & 2.46 & High & 3.60 & $\begin{array}{c}\text { Very } \\
\text { High }\end{array}$ \\
\hline $\begin{array}{l}\text { Entrepreneurship } \\
\text { Knowledge }\end{array}$ & 2.03 & High & 3.20 & $\begin{array}{c}\text { Very } \\
\text { High }\end{array}$ \\
\hline $\begin{array}{l}\text { Approxite } \\
\text { Technology } \\
\text { Knowledge }\end{array}$ & 1.55 & Low & 3.20 & $\begin{array}{c}\text { Very } \\
\text { High }\end{array}$ \\
\hline
\end{tabular}

Based on Table 1., the PjB2L learning model is effective in improving students' technopreneurship abilities. In the interpersonal aspect of the pretest score of 2.47 increased to 3.52 (very high category), the intrapersonal 
IJAMSR 3 (4) www.ijamsr.com CrossRef: https://doi.org/10.31426/ijamsr.2020.3.4.3211

\section{J A M S R}

\section{International Journal of Advanced Multidisciplinary Scientific Research (IJAMSR) ISSN:2581-4281}

aspect of the pretest score of 2.46 increased to 3.60 (very high category), aspects entrepreneurship knowledge from a score of 2.03 increased to 3.20 (very high category), and aspects Approximate technology knowledge from a score of 1.55 increased to 3.20 (very high category). If observed from the four competencies, the biggest increase is in aspects of Approxite Technology Knowledge. The use of this technology is very influential for students because it is a new and interesting thing to learn. Students can directly apply technology in a given project. Some even consider that the entrepreneurship project given is like playing but can make money. So that it is more motivating for students to study. This innovative attitude arises with training and needs. The more often students practice with the amount of demand given, the more they will get used to innovating (Wirahadi Ahmad, A., \& Dwi Haryadi, A. (2011).

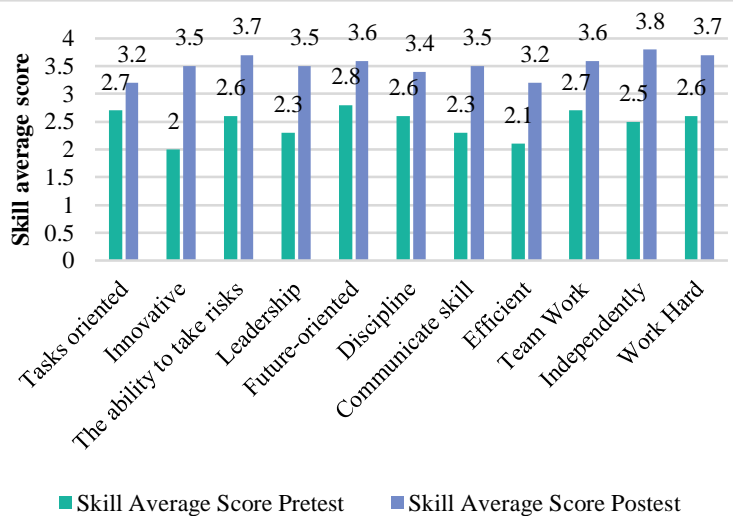

Figure 3. Interpersonal Skill Result

Interpersonal skills are owned by each individual and are related to verbal and nonverbal skills. More precisely is the skill to manage by themselves effectively in working with others in order to complete work together. This ability is in the form of interpersonal attitudes and behaviors known as abilities in teamwork. In this research aspects of interpersonal skills are measured based on 11 indicators namely trust, task-oriented, innovative, risk-taking ability, leadership, future-oriented, discipline, communication skills, efficient, teamwork, independent, hardworking.

Based on Figure 3, the results of the study show that the average interpersonal ability of students increases after the learning process. This increase can be seen based on the value of the pretest and posttest conducted on each aspect of interpersonal skills. Increased ability 
IJAMSR 3 (4) www.ijamsr.com CrossRef: https://doi.org/10.31426/ijamsr.2020.3.4.3211

\section{J A M S R}

\section{International Journal of Advanced Multidisciplinary Scientific Research (IJAMSR) ISSN:2581-4281}

in the high category based on the Gain Score test $(\mathrm{g}>0.7)$ lies in the indicators of trust, innovation, ability to take risks, leadership, future-oriented, communication skills, teamwork, independence, and hard work. Increased ability in the medium category based on the Gain Score test $(0.3 \leq \mathrm{g} \leq 0.7)$ lies in the task-oriented, disciplined, and efficient indicators. There was no increase in the low category.

Project assignments in the theme of technopreneurship through a combination of learning models PjB2L makes students able to interact and communicate with teams very well. Students together are able to complete the given project. In the process, of course this will be able to improve communication skills, cooperation, and hard work. On the other hand, students also practice leadership in managing the job description in teams, trusting the team, dare to take risks to obtain maximum results, be innovative, and work independently to fulfill the given project assignments. These skills are important in improving students' technopreneurship abilities (Saputra, NE, Ekawati, YN, \& Annisa, V. (2020, January). (Bonnstetter, BJ (2012).

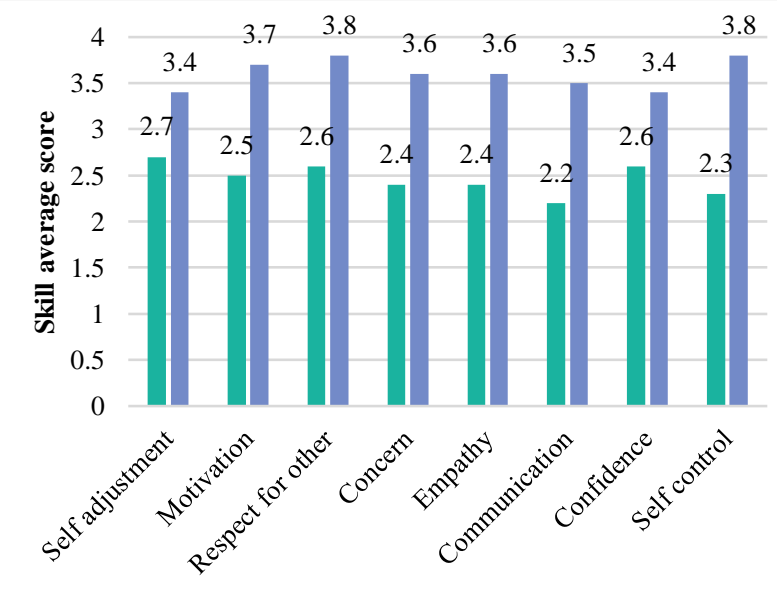

- Skill Average Score Pretest $\quad$ Skill Average Score Postest

Figure 4. Intrapersonal Attitude Trial Results

Intrapersonal skill is intelligence that lies in each individual that is characterized by the ability to understand oneself and act according to that understanding. Thus, every individual who has intrapersonal abilities can accurately understand what is happening to him. In this study aspects of intrapersonal skills are measured based on 8 indicators namely selfadjustment, motivation, respect for others, attention, empathy, communication, cooperation, and the ability to hold back. These eight indicators are tested on students to know their abilities. Based on Figure 4, the increase in indicators in the high category according to the Gain Score test $(g>0.7)$ lies in the ability of motivation, respect for others, attention, 
IJAMSR 3 (4) www.ijamsr.com CrossRef: https://doi.org/10.31426/ijamsr.2020.3.4.3211

\section{International Journal of Advanced Multidisciplinary Scientific Research (IJAMSR) ISSN:2581-4281}

empathy, communication, and the ability to hold back.

Intrapersonal skills need to be possessed by every student to actualize themselves. Rangarajan, R., Jayamala, C., \& Lakshmi, R. (2014). In the current technological era, the ability of each individual is crucial to his success. This ability needs to be trained and applied by students in daily life. Through the $\mathrm{PjB} 2 \mathrm{~L}$ learning concept which is a combination of project-based learning with online learning, students can practice their abilities (Kusumawardani, H., \& Triyono, MB (2017, September).

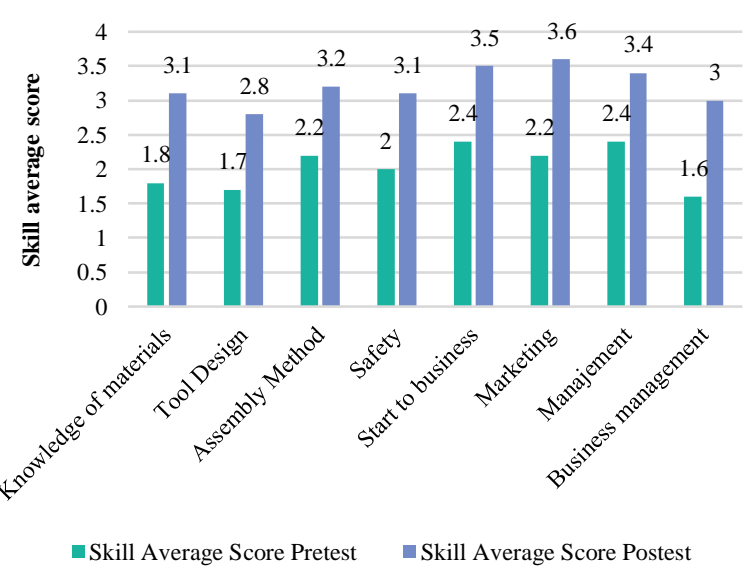

Figure 5. Technopreneurship Knowledge Testing Results

The ability of entrepreneurs, especially technology-based (technopreneurship) must continue to be improved. Progress of the times, all digitalization based will certainly greatly affect the business world. In this study, the ability of technopreneurship is measured based on 8 indicators namely knowledge of material, mastery of tools, assembly methods, security, ability to start a business, marketing, management, and business management. Increasing the ability of technopreneurship in the high category lies in marketing indicators. This is because students have applied the marketing concept both offline and online. Especially for online marketing, students have used various platforms such as websites, social media, and online market places to improve their business.

In its implementation, student entrepreneurship products have been integrated with technology both in terms of products and in their marketing systems (Scarlat, C. (2014). In terms of products, the use of technology starts from the production process to the packing process. In the marketing system, students also have used an online platform to further increase profits. The technology used is an efficient and effective way in terms of cost and time so as to produce a quality product with regard to market needs (Nurdiyanto, H. (2018). 
IJAMSR 3 (4) www.ijamsr.com CrossRef: https://doi.org/10.31426/ijamsr.2020.3.4.3211

\section{International Journal of Advanced Multidisciplinary Scientific Research (IJAMSR) ISSN:2581-4281}

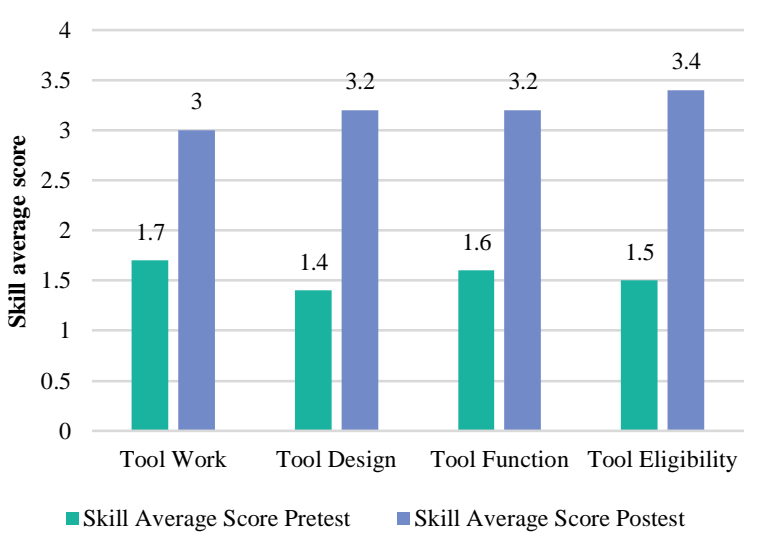

Figure 6. Appropriate Technology Product Testing Results

This appropriate technology was created in an effort to facilitate work, improve product quality, time and cost efficiency, and of course increase profits. In this study, the use of appropriate technology in entrepreneurship was analyzed based on four factors: tool work, tool design, tool function, and tool eligibility. In general the use of technology is in the medium category. Examples of tools used are the use of an oil-draining spinner machine in the production of fried onions. The results of interviews with students, there are many benefits from the application of this technology such as reducing oil content in fried onions, improving product quality because it is more durable, able to reduce blood cholesterol as a result of the type of fried food, and certainly more time efficient than having to drain on a container ordinary.

Another example when viewed from the use of technology in terms of marketing (Kamarudin, HS, \& Sajilan, S. (2013) (Wahyudi, SE, Tileng, KG, \& Kurniawan, IB (2018). Based on the results of research conducted, there are 5 types of online marketing strategies carried out by students. First is social media marketing. Product offerings through social media networks are made with interesting content to attract consumers. The choice of media used 46\% through Facebook, 34\% through tweeters, $20 \%$ through Instagram. Second is mail marketing. This strategy is very easy to do and marketing can be done for free. Students only make interesting marketing content in the form of sentences or pictures and then just send it to the consumer's email address. Third is through the website. This marketing strategy is carried out by students using free websites on blogspot or wordpress. But you can also use paid domains like .com, .co.id, or other paid domains. Of course a paid domain will further convince buyers to increase trust. Fourth is mobile marketing. This mobile marketing strategy utilizes smartphones. The media used by students are WhatsApp and line. In the 
IJAMSR 3 (4) www.ijamsr.com CrossRef: https://doi.org/10.31426/ijamsr.2020.3.4.3211

\section{International Journal of Advanced Multidisciplinary Scientific Research (IJAMSR) ISSN:2581-4281}

WhatsApp application, students utilize WA status for promotional media, create groups for consumers, and there are also those who offer directly to consumers through personal WA. Fifth is video marketing. This strategy is carried out by students using YouTube media and also through media networks with live broadcast mode. Please note that not everyone likes the appearance of images. Many also like the appearance of the product directly. So that the product display will look more detailed.

Table 2. Correlation of PJB2L Learning Model with Technoprneurship Ability

\begin{tabular}{|c|c|c|c|}
\hline \multicolumn{4}{|c|}{ Correlations } \\
\hline & & PjB2L_Model & $\begin{array}{l}\text { Technopreneurship } \\
\text { Ability }\end{array}$ \\
\hline \multirow[t]{3}{*}{ PjB2L_Model } & $\begin{array}{l}\text { Pearson } \\
\text { Correlation }\end{array}$ & 1 & $.523 * *$ \\
\hline & $\begin{array}{l}\text { Sig. (2- } \\
\text { tailed) }\end{array}$ & & .000 \\
\hline & $\mathrm{N}$ & 151 & 151 \\
\hline \multirow[t]{3}{*}{$\begin{array}{l}\text { Technopreneurship } \\
\text { Ability }\end{array}$} & $\begin{array}{l}\text { Pearson } \\
\text { Correlation }\end{array}$ & $.523 * *$ & 1 \\
\hline & $\begin{array}{l}\text { Sig. (2- } \\
\text { tailed) }\end{array}$ & .000 & \\
\hline & $\mathrm{N}$ & 151 & 151 \\
\hline
\end{tabular}

**. Correlation is significant at the 0.01 level (2tailed).

Based on the Table, the Significance value of Sig. (2-tailed) between the Project-Based Blended Learning (PjB2L) model to the students' technoprenuership ability of 0,000 $<0.05$. This means that there is a significant correlation between the independent variables and the dependent variable. Characteristics of Project-Based Learning models that are student-centered, enhance the ability to work together, practice project management, and apply knowledge gained in schools with real problems in life. PPA emphasizes the ability to solve problems and apply the knowledge gained in learning with practical situations that will be faced in the future (Pratama, H., \& Prastyaningrum, I. (2019, February). If combined with a blended learning model in its application, then it will be able to make students actively learn.

\section{Conclusions and Recommendations}

The Project-Based Learning and Blended Learning (PjB2L) model scenario applied in this study consists of 11 steps, namely Define the problem and identify the information needed, Identify Information Seeking Strategies, Locate and access information, Extract Relevant information, Synthesize information, Evaluate the results of research, Communicate the information, Take appropriate action, Finalize the project, Present your final program / activity to the appropriate groups, and Assess your course of action, presentation, and the need for possible further 
IJAMSR 3 (4) www.ijamsr.com CrossRef: https://doi.org/10.31426/ijamsr.2020.3.4.3211

\section{J A M S R}

\section{International Journal of Advanced Multidisciplinary Scientific Research (IJAMSR) ISSN:2581-4281}

action on your topic. The correlation test results show that there is a significant correlation between the Project-Based Blended Learning (PjB2L) model and the students' technoprenuership ability and is proven by the Sig. (2-tailed) of 0,000 .

Technopreneurship Competency is measured based on 4 aspects, namely Interpersonal Skill, Intrapersonal Skill, Entrepreneurship Knowledge, and Approxite Technology Knowledge with an average posttest in the very high category. This shows that the $\mathrm{PjB} 2 \mathrm{~L}$ learning model has a positive effect on improving technoprenuership abilities.

\section{Acknowledgment}

Thank you to the Ministry of Research, Technology and Higher Education who have funded this research through the 2020 Basic Research grant.

\section{References}

1) Ammann, D., Vignoli, Y., \& KaapFröhlich, S. (2019). How can problembased learning be realised in blended learning format? Contribution to the HoGe conference 2018 „Digital learning and teaching "/Wie kann problembasiertes Lernen im Blended-Learning-Format umgesetzt werden? Beitrag zur HoGeTagung 2018 ,Digitales Lernen und Lehren “. International Journal of Health Professions, 6(1), 90-96.
2) Bonnstetter, B. J. (2012). New research: The skills that make an entrepreneur. Harvard Business Review, 90(12), 7.

3) Car, L. T., Kyaw, B. M., Dunleavy, G., Smart, N. A., Semwal, M., Rotgans, J. I., ... \& Campbell, J. (2019). Digital problembased learning in health professions: systematic review and meta-analysis by the Digital Health Education Collaboration. Journal of medical Internet research, 21(2), e12945.

4) Hidayat, H., Kusumaningrum, I., \& Mardin, A. (2017). Needs analysis of entrepreneurships pedagogy of technology and vocational education with production base learning approach in higher education. International Journal on Advanced Science, Engineering and Information Technology, 7 (5), 1701-1707.

5) Hidayat, H., Tamin, BY, Herawati, S., Khairul, K., \& Syahmaidi, E. (2019). The contribution of technopreneurship scientific learning and learning readiness towards the entrepreneurship learning outcomes in higher vocational education. Journal of Vocational Education, 9 (1), 21-32.

6) Ismail, E., Samsudi, S., \& Widjanarko, D. (2017). Development of Technopreneurship Learning Models in Vocational High School Machinery Program. Journal of Vocational and Career Education, 2 (2).

7) Kamarudin, HS, \& Sajilan, S. (2013). Critical success factors of technopreneurship in the creative industries: a study of animation ventures. Review of Integrative Business and Economics Research, 2 (1), 1.

8) Khasanah, M. (2019). The Influence of the Use of Moodle-Based E-Learning Media and Learning Interests on Learning Outcomes of Craft and Entrepreneurship. Academics, 8 (1). 
IJAMSR 3 (4) www.ijamsr.com CrossRef: https://doi.org/10.31426/ijamsr.2020.3.4.3211

9) Kusumawardani, H., \& Triyono, MB (2017, September). The Soft Skill of Fashion Student for Entrepreneurship. In the 1st International Conference on Social, Applied Science and Technology in Home Economics (ICONHOMECS 2017). Atlantis Press.

10) Lalima, DK, \& Dangwal, KL (2017). Blended learning: An innovative approach. Universal Journal of Educational Research, 5 (1), 129-136.

11) Ma, H. (2016). A study of blended learning strategies for project-based studies. Asia Pacific Journal of Contemporary Education and Communication Technology, 2 (1), 50-57.

12) Nurdiyanto, H. (2018). A work-based learning model with technopreneurship. Glob. J. Eng. Educ, 20 (1), 75-78.

13) Okorie, NN, Kwa, DY, Olusunle, SOO, Akinyanmi, AO, \& Momoh, IM (2014). Technopreneurship: An urgent need in the material world for sustainability in Nigeria. European Scientific Journal, 10 (30).

14) Rangarajan, R., Jayamala, C., \& Lakshmi, R. (2014). Influence of emotional intelligence on business sustainability of entrepreneurs: A study with special reference to select entrepreneurs in Chennai. Management Insight, 10 (2), 110.

15) Saputra, NE, Ekawati, YN, \& Annisa, V. (2020, January). Characteristics of Jambi University student entrepreneurs. In Proceedings of the National Seminar in Masters in Psychology at Ahmad Dahlan University (pp. 14-26).

16) Scarlat, C. (2014). Technopreneurship-An Emerging Concept. FAIMA Business \& Management Journal, 2 (3), 5.

17) Shimizu, I., Nakazawa, H., Sato, Y., Wolfhagen, IH, \& Könings, KD (2019). Does blended problem-based learning make Asian medical students active learners ?: a prospective comparative study. BMC medical education, 19 (1), 147.
18) Suharto, TW, Maduretno. 2020. The Effectiveness of Entrepreneurship Development Program through the ProjectBased Learning Model to Entrepreneurial Soul of College Students. International Journal of Advanced Multidisciplinary Scientific Research (IJAMSR), 3 (2), 13-25.

19) Suwono, H., \& Dewi, EK (2019, March). Problem-based learning blended with online interaction to improve motivation, scientific communication and higher order thinking skills of high school students. In AIP Conference Proceedings (Vol. 2081, No. 1, p. 030003). AIP Publishing LLC.

20) Wahyudi, SE, Tileng, KG, \& Kurniawan, IB (2018). Enhancing Students' Technopreneurship Projects with Mobile Collaboration and Communication Applications. Journal of Telecommunication, Electronic and Computer Engineering (JTEC), 10 (2-3), 129-134.

21) Wahyudi, W., \& Winanto, A. (2018). Development of Project-based Blended Learning (PjB2L) Model To Increase PreService Primary Teacher Creativity. Journal of Educational Science and Technology (EST), 4 (2), 91-102.

22) Walker, K. (2012). The technopreneurship process: Academic entrepreneur university spin-offs. RIThink, 2, 11-22.

23) Wirahadi Ahmad, A., \& Dwi Haryadi, A. (2011). Efforts to Increase Motivation and Entrepreneurship Learning Outcomes Through a Combination of 5 Learning Techniques in Padang State Polytechnic Students. Journal of Accounting \& Management, 6 (2), 23-39.

24) Yulastri, A., \& Hidayat, H. (2017). Developing an Entrepreneurship Module by Using Product-Based Learning Approaches in Vocational Education. International Journal of Environmental and Science Education, 12 (5), 1097-1109. 